\title{
Comparison of Streptozotocin and Alloxan-Induced Diabetes in the Rat, Including Volumetric Quantitation of the Pancreatic Islets*
}

\author{
V. Hoftiezer, ${ }^{* *}$ and A-M. Carpenter \\ Department of Anatomy University of Minnesota, Minneapolis, Minnesota, USA
}

Received: June 6, 1972, accepted: January 16, 1973

\begin{abstract}
Summary. Diabetes was induced in rats with equal molar dosages of either streptozotocin or alloxan. The clinical course of the diabetes (mortality, hyperglycemia, weight loss, polydipsia, hyperphagia, polyuria, glycosuria and diabetic indices) was recorded for six weeks before the animals were sacrificed for volumetric quantitation of the pancreatic islets. No significant differences in the pancreas (islet volumes of pancreas; beta, alpha and non-granular cell volumes and vessel volumes of both islet and total pancreas) were seen between the two groups, although differences in the clinical para-
\end{abstract}

meters were observed. The diabetic index at three and four weeks post injection was the clinical parameter which best reflected the terminal pancreatic beta cell volume. Analysis of the scanning data adds further empirical support for the accuracy of the linear scan method of quantitation.

Key words: Streptozotocin, alloxan, diabetes, quantitation, islet volume, beta cell volume, alpha cell volume, vessel volume.
Streptozotocin is becoming increasingly popular as a diabetogenic agent $[1-23]$. Although the early workers reported only degranulation of the beta cells of the pancreatic islets without necrosis after streptozotocin administration $[1,14]$, streptozotocin probably produces diabetes by causing a selective necrosis of the pancreatic beta cells $[2,8,9,13,21,23,24]$. Streptozotocin made available and used prior to 1965 may have been contaminated with an impurity [5, 8] which could explain the conflicting reports on the effects of streptozotocin on the beta cells of the pancreatic islets.

A number of anthors have made comparisons of the effects of streptozotocin with those of alloxan, the "classical" diabetogenic agent $[1,4,5,8,9,18,21]$. However, in only a few studies $[7,11,16,17,23,25]$ have comparisons been made directly, using both agents simultaneously in a controlled study.

Our study was designed so that direct comparisons of the effects of streptozotocin could be made with those of alloxan. An attempt was made to standardize streptozotocin, a comparatively new diabetogen, using alloxan, the classical diabetogenic agent, as the standard. Quantitation of the volume of the pancreatic islets was selected as one of the parameters for comparison of streptozotocin- and alloxan-induced diabetes.

\section{Materials and Methods}

\section{Animals and Agents}

Sixty male albino rats (Sprague-Dawley strain from Holtzman Laboratories), weighing $100-150 \mathrm{~g}$ after a $24 \mathrm{~h}$ fast, were used in this study. Equal molar dosages of

* Supported by USPHS Training Grant No. GM 114.

** Present address: V. Hoftiezer, Ph.D., Northwest Center for Medical Education, Indiana University, 3400 Broadway, Gary, Indiana 46408. either streptozotocin ${ }^{1}(65 \mathrm{mg} / \mathrm{kg})$ or alloxan $(40 \mathrm{mg} / \mathrm{kg})$ were administered intravenously (tail vein). The ratio, 0.604 , of the molecular weights of alloxan, 160.08, and streptozotocin, 265.00 , is approximately equal to the ratio, 0.615 , of the dosages of the agents used in this study. Both agents were dissolved in saline previously adjusted to $\mathrm{pH} 4.3$ with $0.05 \mathrm{M}$ citric acid. There were 25 streptozotocin-diabetic rats (SDR) and 24 alloxan-diabetic rats (ADR). Eleven control rats (CR) received equal volumes of acidified saline. Immediately after they were injected, the rats were supplied with Purina Rat Chow and water ad libitum throughout the study, except when food was withheld prior to glucose tolerance testing. The animals were followed clinically for six weeks to determine the course of the resulting diabetes.

\section{Clinical Studies}

Blood glucose levels were determined on the Auto Analyzer using a modification of Hoffman [26]. Body weight, as well as food and water consumption and urine excretion within a $24 \mathrm{~h}$ period, was recorded at weekly intervals on alternate subgroups throughout the study period. The Somogyi method [27] was used to estimate the amounts of glucose excreted in the urine during the $24 \mathrm{~h}$ periods. Glucose tolerance tests (GTT) were carried out at one and three weeks or at two and four weeks post injection on alternate subgroups. Animals, fasted for $18 \mathrm{~h}$, received $30 \%$ glucose ( $3 \mathrm{~g} / \mathrm{kg}$ body weight) intravenously; blood samples were drawn from the tail at onehalf, one and $2 \mathrm{~h}$ post injection for determination of blood sugar (BS) levels (in milligram per cent). A diabetic index was calculated from the results of the GTT using the following formula [28]:

$\mathrm{I}_{\mathrm{D}}=\frac{1 \mathrm{~h} \text { experimental BS }}{\text { av. normal } 1 \mathrm{~h} \mathrm{BS}} \times \frac{2 \mathrm{~h} \text { experimental blood sugar }}{\text { av. normal } 2 \mathrm{~h} \text { blood sugar }}$

The average normal blood sugar values, determined from standardized values obtained from a large group of normal rats in our department, were 200 and 107 milligrams per cent ( $\mathrm{mg} \%$ ), respectively,

1 Streptozotocin, Lot No. U-9889 46-HJK-126D, was provided through the courtesy of Dr. W.E. Dulin of the Upjohn Co., Kalamazoo, Michigan. 


\section{Tissue Preparation}

Six weeks following injection, the animals were sacrificed by decapitation. The total pancreas was removed and fixed in Bouin's fixative for $4 \mathrm{~h}$. After routine dehydration, the tissue was double infiltrated with celloidin and paraplast. Sequential sections, four miorons thick, at 400 micron intervals (every 100 th section) from the entire pancreas, were mounted on glass slides and stained with Carpenter's modification of Gomori's aldehyde fuchsin [29] and counterstained with ponceau.

\section{Quantitation}

Aldehyde fuchsin-ponceau stained sections from randomly selected pancreases were scanned using the micrometer component quantitator $[30,31]$. Islet volume, expressed as per cent of the total pancreas, was determined at low power (10X objective) with traverse inter. vals of one millimeter $(\mathrm{mm})$. The total linear scan for each determination was $500 \mathrm{~mm}$ or more. The relative volumes of the various components of the islets, expressed as per cent of total islet, were measured at high magnification, using an oil immersion objective, with traverse intervals of 20 micra. Five $\mathrm{mm}$ of total linear scan were completed for each animal. The components of the islet also were expressed as per cent of the total pancreas by multiplying the volume per cent of the islet of each component by the islet volume of the total pancreas.

\section{Identification of Islet Components}

The classification of cells of the islet was patterned after that of Carpenter and Lazarow [32]. Color plates $1-3$ on page 495 of their article should be seen for further details. In aldehyde fuchsin stained material, beta cells, containing varying numbers of granules, were classified on a scale from $1+$ to $4+$ granulation. Cells without granules, but with pale blue cytoplasm, were seen, especially in the experimental animals; these cells were identified as non-granular cells in this study. The finely granular cytoplasm of the alpha cells stained varying tints of pink with ponceau. Thus, the distinction between alpha cells and the non-granular cells could be made easily.

The component identified as vessel included the lumen and the endothelial lining of the capillaries within and surrounding the islet.

Because the number of micrometers limited the number of components that could be quantitated per scan to five, the designations were: 1) $3-4+$ beta cells (beta cells containing more than half of the full complement of granules), 2) $1-2+$ beta cells (beta cells containing less than half of the full complement of granules), 3) nongranular cells, 4) alpha cells, and 5) vessels.

\section{Results}

\section{Clinical Study}

All the experimental animals became diabetic after a single i.v. injection of either of the two diabetogens.

Mortality was highest in the ADR (Table 1). $42 \%$ of all the mortalities (eight out of 19) occurred during the GTT procedure, usually immediately following the glucose injection. Death of ten of the ADR, bat only one SDR was due to factors other than the stress of the GTT. The clinical results include data only from the rats that survived the six week study period.

The level of hyperglycemia was consistently lower among the SDR than among the ADR (Fig. 1). The mean blood sugar level of the SDR was $408 \pm 75^{1} \mathrm{mg} \%$ after the first week; during the last five weeks, the average blood glucose levels were between 450 and $500 \mathrm{mg} \%$. The ADR showed an average blood sugar level of $493 \pm 70 \mathrm{mg} \%$ the first week which increased

Table 1. Survival and mortality of rats. Six weeks after injection. The $C R$ groups represents the control rats, white the SDR and $A D R$ groups represent the streptozotocin diabetic rats and the alloxan-diabetic rats respectively

\begin{tabular}{|c|c|c|c|}
\hline Group & $\begin{array}{l}\text { Number } \\
\text { of Rats } \\
\text { injected }\end{array}$ & $\begin{array}{l}\text { Rats alive at } \\
\text { of six weeks } \\
\text { Number }\end{array}$ & $\begin{array}{l}\text { the end } \\
\text { Per cent }\end{array}$ \\
\hline$\overline{\mathrm{CR}}$ & 11 & 10 & 90.9 \\
\hline SDR & 25 & 22 & 88.0 \\
\hline ADR & 24 & 9 & 37.5 \\
\hline
\end{tabular}

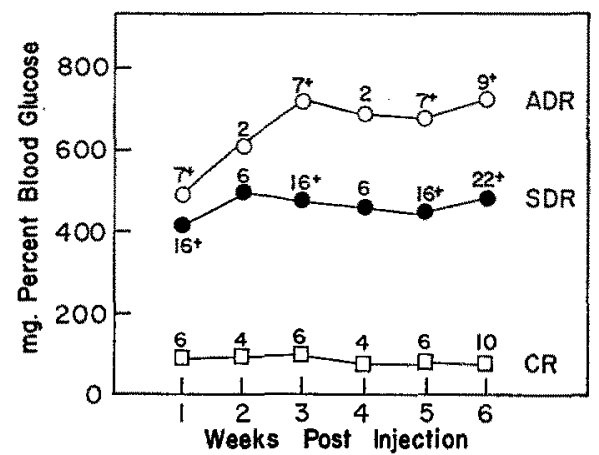

Fig. 1. Mean blood sugar values. The mean values are represented by open squares $(\square-\square)$ for the control rats (CR), by filled circles (-) for the streptozotocindiabetic rats (SDR), and by open circles $(O-O)$ for the alloxan-diabetic rats (ADR). The numbers indicate the number of animals used for determination of the mean. The + symbol indicates a significant difference of the means at the $p<0.01$ level

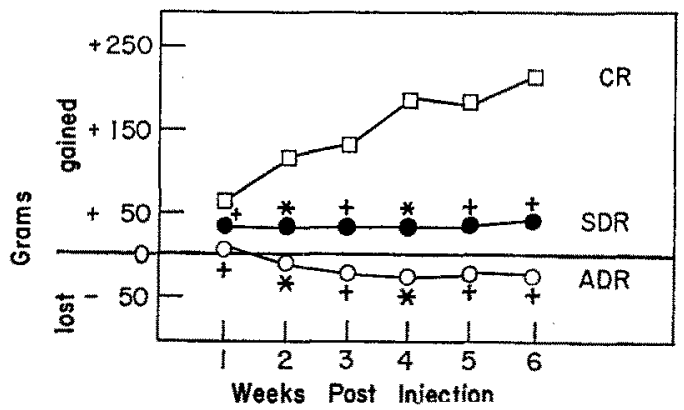

Fig. 2. Mean changes in body weight from injection. The symbols used indicate the same values as those in Fig. 1, with the addition of the * symbol to represent a significant difference of the means at the $p<0.05$ level

to $620 \pm 240 \mathrm{mg} \%$ the second week and to $730 \pm 203$ $\mathrm{mg} \%$ the third week; during the last three weeks, the average blood glucose levels were between 680 and $722 \mathrm{mg} \%$. The CR maintained average blood sugar levels below $100 \mathrm{mg} \%$ at all times tested.

1 t one standard deviation of the mean. 
The average changes in body weight were inversely related to the blood sugar levels of the animals (Fig. 2). The SDR maintained their injection weight level, while the ADR lost weight. The CR gained an average of $215 \mathrm{~g}$ over their initial weight. Fig. 2 does not show actual weight lost or gained since all animals were experimental groups displayed hyperphagia. However, the SDR consumed significantly more food per $24 \mathrm{~h}$ period at three, five and six weeks post injection than did the ADR. Polyuria was greater in the ADR than in the SDR during the first and second week after injection, but during the last four weeks, the SDR ex-
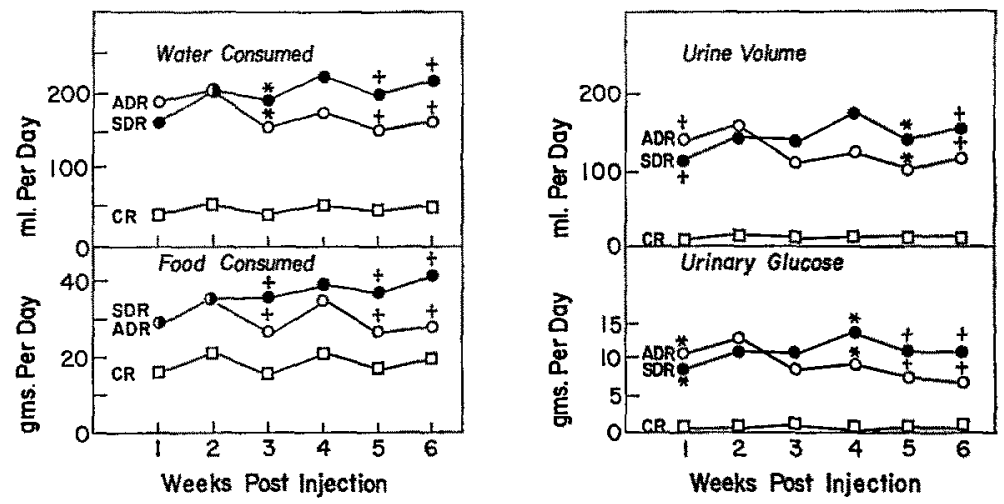

Fig. 3. Water and food consumption, urine volume and amounts of sugar excreted in the urine. The symbols used are the same as those used for Figs. 1 and 2

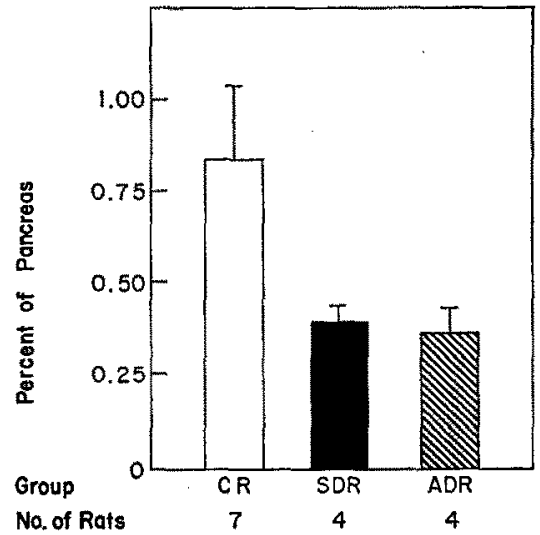

Fig. 4: Mean islet volumes of the pancreas. One standard deviation of the mean is shown by the vertical line (T). The groups are the same as those designated in Table 1

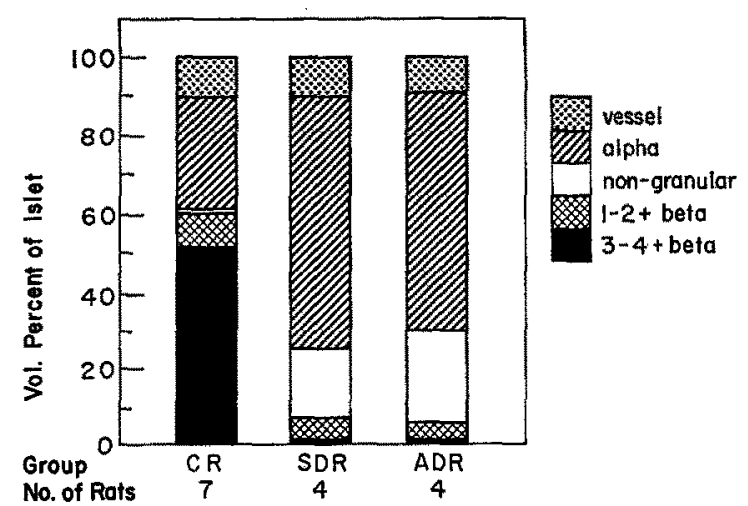

Fig. 5. Mean relative volumes of the components of the islet (as per cent of the total islet). The groups are the same as those designated in Table 1

Table 2. Mean diabetic index. The groups are the same as those designated in Table 1. The mean diabetic index \pm one standard deviation is given for each time period post injection. The number in parenthesis represents the number of rats used for each determination. The asterisk (*) indicates a significant difference of the means at the $p<0.05$ level

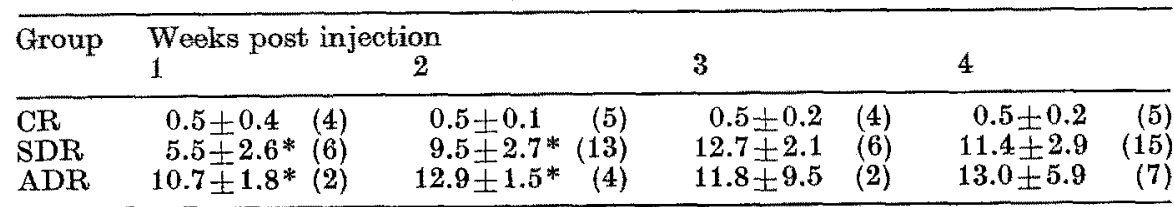

fasted on alternate weeks for GTT and had to compensate for that weight loss.

The degree of polydipsia was closely related to both polyuria and glycosuria (Fig. 3). The SDR consumed significantly more water per $24 \mathrm{~h}$ at the fifth and sixth week post injection than did the ADR. Both creted a larger average volume of urine per $24 \mathrm{~h}$ than did the ADR; the differences were not significant until the sixth week when the SDR excreted an average volume of $155 \pm 36$ milliliters (ml) of urine per $24 \mathrm{~h}$ compared to $1 \overline{15} \pm 36 \mathrm{ml}$ excreted by the ADR. The urine excreted by the CR never exceeded an average of 
$10 \mathrm{ml}$ per $24 \mathrm{~h}$. The average amount of glucose excreted in the urine followed the same pattern as the urine volume for each of the three groups (Fig. 3). The levels of glycosuria of the two diabetic groups were significantly different at five and six weeks post injection; the SDR excreted $10.8 \pm 2.7 \mathrm{~g}$ and $11.7 \pm 2.8 \mathrm{~g}$ of glucose per $24 \mathrm{~h}$ compared to $7.2 \pm 2.9 \mathrm{~g}$ and $8.8 \pm$ $2.4 \mathrm{~g}$ excreted by the ADR. The level of glucose in the urine of the CR averaged less than $0.03 \mathrm{~g}$ per $24 \mathrm{~h}$ at all intervals tested.

The average diabetic indices $\left(I_{D}\right)$ of the two experimental groups did not differ at the $p<0.01$ level (Table 2), although the $\mathrm{I}_{\mathrm{D}}$ of the SDR were lower than those of the ADR at the first and second weeks post injection $(p<0.05)$. If the two $\mathrm{I}_{\mathrm{D}}$ obtained from the same SDR are compared (week one with week three) the difference is significant at the $p<0.01$ level.

\section{Quantitative Scanning}

There was no significant difference in the average islet volume of the pancreas between the SDR $(0.39 \pm$ $0.06 \%)$ and the $\operatorname{ADR}(0.36 \pm 0.07 \%)$, although both were significantly reduced from that of the CR $(0.83 \pm$ $0.20 \%$ ) (Fig. 4). The islet volumes were reduced from the control values by $53.0 \%$ in the SDR and by $56.6 \%$ in the ADR.

The average relative volumes of the components of the islets of the two diabetic groups did not vary significantly (Fig. 5). In both groups the average total beta cell volume was reduced from that of the CR $(59,7 \%$ with $50.8 \%$ being $3-4+$ granulated $)$. Streptozotocin reduced the average total beta cell volume of the animals to $5.9 \%$ with only $0.5 \%$ being $3-4+$ granulated, while alloxanization resulted in an average total beta cell volume of $5.1 \%$ with $0.6 \%$ having 3 $4+$ granulation. The non-granular cell volume of the islets averaged $18.5 \%$ in the SDR and $23.8 \%$ in the ADR compared with $0.4 \%$ in the controls. The average alpha cell volumes of the islet of both the SDR $(62.2 \%)$ of the ADR $(61.8 \%)$ were greater than that of the CR $(29.6 \%)$. The average vessel volume of the islet remained unchanged among the three groups - $10.3 \%$ in the CR, $10.4 \%$ in the SDR and $9.3 \%$ in the ADR.

The differences between the volumes of the components of the islet of the diabetic animals and those of the CR are more obvious when the values are expressed as volume per cent of the total pancreas (Fig. 6 ). The average total beta cell volume of the pancreas in both groups of diabetic animals is reduced by about $96 \%$ from that of the controls. Although the average non-granular cell volume of the pancreas increased in the experimental groups, it is not enough to compensate for the loss in the beta cell volume of the pancreas. The combined volumes of the beta cells and the non-granular cells within the two groups represent an $80 \%$ reduction from the combined values in the CR. In contrast to the component volume of the islet, the average alpha cell volume of the pancreas did not differ significantly among the three groups. The islet vessel volume as per cent of the total pancreas was reduced from that of the CR by $52.9 \%$ for the SDR and by $61.2 \%$ for the ADR. The total cell mass of the islet (beta + non-granular + alpha cells) as a per cent of the total pancreas was reduced from that of the CR by $53.3 \%$ for the SDR and by $56.4 \%$ for the ADR.

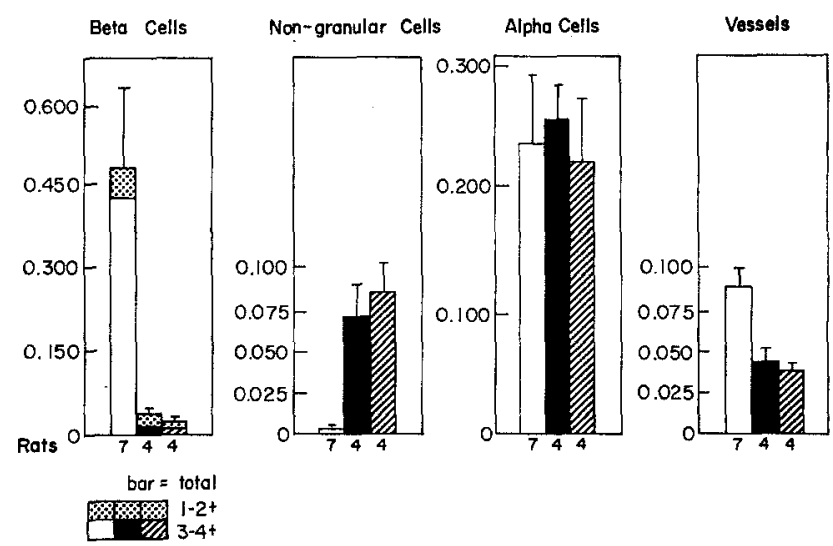

Fig. 6. Mean relative volumes of the components of the islet (as per cent of the total pancreas). The open bars (प) represent the mean values of the control rats, the filled bars (I) represent mean values of the streptozotocin-

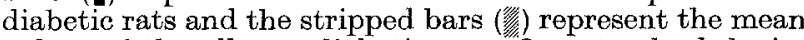
values of the alloxan-diabetic rats. One standard deviation of the mean is shown by the vertical line $(T)$ and the numbers below the bars indicate the number of rats used for each determination

\section{Discussion}

The present study confirms the observation of others $[1,4,8,9,15,23,24]$ that streptozotocin is as effective a diabetogen as is alloxan when either agent is given intravenously. Mortality among the rats, excluding GTT deaths, was 10 times greater with alloxan $(40.0 \%)$ than it was with streptozotocin $(3.7 \%)$. The clinical courses of the diabetes induced by either streptozotocin or alloxan were similar, but not identical. The levels of hyperglycemia (Fig. 1) and the changes in body weight (Fig. 2) did not correlate with the degree of polydipsia, hyperphagia, polyuria and glycosuria (Fig. 3). The explanation for these differences may be due to extrapancreatic effects, such as a difference in the renal toxicity of the two beta cytotoxins. The nephrotoxic effects of alloxan are well established. It has been suggested that streptozotocin is more selective for beta cells with less general toxicity than is alloxan $[1,8,9]$. Also streptozotocin depresses the hepatic NAD levels, while alloxan does not [51]. There was no significant difference between the diabetic indices of two experimental groups at three and four weeks after injection. The diabetic indices of SDR may reflect a gradual decrease in the tolerance to glucose with time, supporting the suggestion of Dulin, et al. [4] that the severity of streptozotocin diabetes increases gradually. 
The results of quantitation of the pancreas show no significant difference between SDR and ADR (Fig. 4). The average islet volume of the seven $C R$ was $0.83 \pm 0.20 \%$ of the total pancreas. Other investigators using the linear scan method on rats have reported normal average islet volumes of $0.69,1.16$ and $1.29 \%$ [33] and $1.22 \%[3,34]$. The lower islet volume in the present study is attributed to the younger age of the rats used. Both the number $[35,36,37]$ and the volume $[38,39,40,41]$ of islets are reported to increase with age. The average age of the rats used here was 49 days. Presumably, the other workers used rats considerably older than 50 days. The size of the litter from which an animal comes also is reported to influence islet volume [42].

The component volumes of the islet found in this study (Fig. 5) compare favorably with those previously reported using the same method, with the exception of the alpha cell volume of the islet $[32,33]$. The beta cell volume in our study, $59.7 \%$, is within the range, $56.6 \%$ to $71.3 \%$, reported by Carpenter and Lazarow [32] and Wright [33]. These same authors [32, 33] found alpha cell volumes ranging from 13.9 to $21 \%$ and vessel volumes of 11.8 to $16 \%$. The vessel volume from this study $(10.3 \%)$ falls into the lower range of the previous studies. The alpha cell volume is higher than that found in comparable studies of normal rats. However, Hellman [43], using another method of quantitation, found that age influences the alpha: beta cell ratio in rats. He found more alpha cells in newborn animals than in adult rats 100 days of age. Petersson, et al. [42] noted that rats from large litters had increased beta: alpha cell ratios, due to lower numbers of alpha cells, than animals of the same age from small litters. Thus, it is felt that the difference in alpha cell volume in this study is due to factors other than variations in cell identification or application of the linear scan method. Non-granular cells have not been reported in the islets of normal animals by investigators using similar staining and identification methods $[32,33,34,44]$. Carpenter and Lazarow [32] reported that non-granular cells appeared in normal animals four hours after glucose injection. The non-granular cells seen in CR in this study occurred in only three rats which had received two injections of glucose for the GTT during the six week observation period. The true identity of these cells is unknown $[32,34]$.

The decrease in islet volume of the pancreas (Fig. 4) of the diabetic animals could be due to a decrease in either the size or the number of islets in the pancreas. If entire islets were destroyed a decrease in the alpha cell volume of the pancreas would be expected. However, the fact that the alpha cell volume of the total pancreas remains within normal limits (Fig. 6), suggests that the decreased islet volume of the pancreas is a result of a decrease in the size of the islets. A normal alpha cell volume of the pancreas also indicates that the increase in the alpha cell volume of the islet (Fig. 5) is a relative increase due to loss of beta cells rather than an actual increase due to proliferation of alpha cells. Wright and Carpenter [45] did not, although Wright [33] did, report a decrease in alpha cell volume of the pancreas of alloxan diabetic and subdiabetic animals concurrent with a decrease in beta cell volume.

A significant decrease in islet vessel volume of the total pancreas was observed in both groups of diabetic animals from that of the controls (Fig. 6). A diminished vessel volume of the pancreas has been observed in alloxanized animals [33], which was attributed to total destruction of some islets. If this were the case in the present study, an actual increase in alpha cells in the remaining islets would have been required to compensate for loss of cells in destroyed islets. Another explanation may be the loss or disappearance of vessels no longer needed to supply the destroyed beta cells. The reduction of the total islet cell mass (the sum of the beta, alpha and non-granular cell volumes of the pancreas) of the pancreas from that of the controls for the SDR $(53.3 \%)$ and ADR $(56.4 \%)$ was approximately the same as the reduction of the islet vessel volumes $(52.9 \%$ and $61.2 \%$ respectively) of the pancreas. This explanation adds further empirical support for the accuracy of the linear scan method of quantitation.

Both streptozotocin and alloxan induce diabetes by acting to produce relative or absolute deficiencies of insulin $[9,15,23,46,47,48,49]$. Presuming that aldehyde fuchsin is insulin [50], the scanning data indicate no morphological differences in the amount of insulin (beta cell granulation) present in the pancreas of the two groups six weeks after the administration of streptozotocin or alloxan. However, similar morphometric measurements would not reflect a differential rate of insulin turnover (ie. synthesis, storage and/or release) between the two groups. The diabetic index was the clinical parameter which best reflected the data obtained from quantitation of the pancreatic beta cell volume.

\section{References}

1. Arison, R.N., Ciaccio, E.I., Glitzer, M.S., Cassaro, J.A., Pruss, M.P.: Light and electron microscopy of lesions in rats rendered diabetic with streptozotocin. Diabetes 16, 51-56 (1967).

2. Brosky, G., Logothetopoulos, J.: Streptozotocin diabetes in the mouse and guinea pig. Diabetes 18, 606-$611(1969)$.

3. Chang, A.Y., Schneider, D.I.: Hepatic enzyme activities in streptozotocin-diabetic rats before and after insulin treatment. Diabetes 20, 71 - 77 (1971).

4. Dulin, W.E., Lund, G.H., Gerritsen, G.C.: Streptozotocin-induced diabetes in the rat. Diabetes 16, $512-513(1967)$.

5. Evans, J.S., Gerritsen, G.C., Mann, K.M., Owen, S.P.: Antitumor and hyperglycemic activity of streptozotocin (NSC-37917) and its cofactor, U-15, 774. Cancer Chemother. Rep. 48, 1-6 (1965).

6. Hoftiezer, V., Carpenter, A.M., Heggestad, C.B.: Early histologic changes in pancreatic islets after streptozotocin administration. Anat. Rec. 166, 319 (1970). 
7. Hoftiezer, V., Carpenter, A.-M., Heggestad, C.B.: Comparison of streptozotocin- and alloxan-induced diabetes in the rat. Anat. Rec. 169, 341 (1971).

8. Junod. A., Lambert, A.E., Orci, L., Pictet, R., Gonet, A.E., Renold, A. E.: Studies of the diabetogenic action of streptozotocin. Proc. Soc. exp. Biol. Med. 126, $201-205$ (1967).

9. Junod, A., Lambert, A.E., Stauffacher, W., Renold, A. E.: Diabetogenic action of streptozotocin : relationship of dose to metabolic response. J. clin. Invest. 48, $2129-2139(1969)$.

10. Lorch, E.: Inhibition of intestinal absorption and improvement of oral glucose tolerance by biguanides in the normal and in the streptozotocin-diabetic rat. Diabetologia 7, 195-203 (1971).

11. Mansford, K.R.L., Opie, L.: Comparison of metabolic abnormalities in diabetes mellitus induced by streptozotocin or by alloxan. Lancet $1968 \mathrm{I}, 670-671$.

12. Petersson, B., Hellerstrom, C., Gunnarsson, R.: Structure and metabolism of the pancreatic islets in streptozotocin treated guinea pigs. Horm. Metab. Res. 2, $313-317(1970)$.

13. Pitkin, R.M., Reynolds, W.A.: Diabetogenic effects of streptozotocin in Rhesus monkeys. Diabetes $\mathbf{1 9}$, $85-90(1970)$.

14. Rakieten, N., Rakieten, M.L., Nadkami, M.V.: Studies on the diabetogenie action of streptozotocin (NSC-37917). Cancer Chemother. Rep. 29, 91-98 (1963).

15. Rerup, C.C.: Drugs producing diabetes through damage of insulin secreting cells. Pharmacol. Rev, 22, $485-518(1970)$.

16. Rerup, C.C., Tarding, F.: Comparison of the experimental diabetes induced by alloxan and streptozotocin in mice. Diabetologia 4, $313(\mathbf{1 9 6 8 )}$.

17. Rerup, C.C., Tarding, F. : Streptozotocin - and alloxandiabetes in mice. Europ. J. Pharmac. 7, 89-96 (1969).

18. Schein, P.S., Bates, R.W.: Plasma glucose levels in normal and adrenalectomized mice treated with streptozotocin and nicotinamide. Diabetes 17, 760765 (1968).

19. Schein, P.S., Alberti, K.G.M.M., Williamson, D.H.: Fffects of streptozotocin on carbohydrate and lipid metabolism in the rat. Endocrinology 89, 827-834 (1971).

20. Schlichtkrull, J.: Recent observations on pro-insulin and on streptozotocin diabetes. Diabetologia 4, 18-19 (1968).

21. Stauffacher, W., Burr, I., Gutzeit, A., Deaven,D., Veleminsky, J., Renold, A.E.: Streptozotocin diabetes: time course of irreversible B-cell damage, further observations on prevention by nicotinamide. Proc. Soc. exp. Biol. Med. 133, 194-200 (1970).

22. Steiner, H., Oelz, O., Zahnd, G., Froesch, E.R.: Studies on islet cell regenoration, hyperplasia and intrainsular cellular interrelations in long lasting streptozotocin diabetes in rats. Diabetologia 6, $558-$ $564(1970)$.

23. Veleminsky, J., Burr, I.M., Stauffacher, W.: Comparative study of early metabolic events resulting from the administration of the two diabetogenic agents alloxan and streptozotocin. Europ. J. clin. Invest. 1, $104-108(1970)$.

24. Schein, P.S., Cooney, D.A., Vernon, M. L.: The use of nicotinamide to modify the toxicity of streptozotocin diabetes without loss of antitumor activity. Cancer Res. 27, 2324-2332 (1967).

25. Logothetopoulos, J., Brosky, G.: Mitotic activity of islet cells in alloxan and streptozotocin diabetic mice studied by radioautography. Diabetes 17, 306 (1968).
26. Hoffman, W.S.: A rapid photoelectric method for the determination of glucose in blood and urine. J. biol. Chem. 120, $51-55$ (1937).

27. Somogyi, M.: A rapid method for the estimation of urine sugar. J. Lab. clin. Med. 26, 1220-1223 (1941).

28. Coupland, R.E., Davidson, J., Lazarow, A.: A dia. betic index in the rat as determined by glucose tolerance tests. Anat. Rec. 124, 394 (1956).

29. Gomori, G.: Aldehyde-fuchsin: a new stain for elastic tissue. Amer. J. clin. Path. 20, 665-666 (1950).

30. Carpenter, A-M., Lazarow, A. : Component quantitation of tissue sections. II. A study of the factors which influence the accuracy of the method. J. Histochem. Cytochem. 10, 329-340 (1962).

31. Lazarow, A., Carpenter, A-M. : Component quantitation of tissue sections. I. Characterization of the instruments. $J$. Histochem. Cytochem. 10, 324-328 (1962).

32. Carpenter, A-M., Lazarow, A. : Effects of hyper and hypoglycemia on beta cell degranulation and glycogen infiltration in normal, subdiabetic and diabetic rats. Diabetes 16, 493-501 (1967).

33. Wright, D.L.: Quantitative studies of pancreatic islet components under various experimental conditions. Doctoral Dissertation. University of Minnesota (1968).

34. Lazarow, A., Carpenter, A-M., Morgan, C., Wright, D.: Effects of long-term administration of tolbut; amide in normal, subdiabetic and diabetic rats. Diabetes 11, 103-114 (1962).

35. Bunnag, S. C.: Postnatal neogenesis of islets of Langerhans in the mouse. Diabetes 15, 480-491 (1966).

36. Hellman, B.: The numerical distribution of the islets of Langerhans at different ages of the rat. Acta endocr. 32, 63-77 (1959).

37. Hellman, B. : The effect of aging on the number of the islets of Langerhans in the rats. Acta endocr. 32, $78-91$ (1959).

38. Haist, R.E.: Factors affecting the islets of Langerhans. Diabetes 2, 295-298 (1953).

39. Haist, R.E., Pugh, E.J.: Volume measurement of the islet of Langerhans and the effects of age and fasting. Amer. J. Physiol. 152, 36-41 (1948).

40. Hellman, B.: The total volume of the pancreatic islet tissue at different ages of the rat. Acta path. microbiol. scand. 47, 35-50 (1959).

41. Hellman, B.: The volumetric distribution of the pancreatic islet tissue in young and old rats. Acta endocr. 31, 91-106 (1959).

42. Petersson, B., Hellerstrom, C., Hellman, B.: The influence of the litter size on the postnatal growth of the islets of Langerhans in the rat. Acta. endocr. 35, $533-540(1960)$.

43. Hellman, B.: The relation between age and the $B / A$ cell ratio in the islet tissue of the rat. Acta endocr. 31, $80-90(1959)$.

44. Carpenter, A-M., Gerritsen, G.C., Dulin, W.E., Lazarow, A.: Islet and beta cell volumes in diabetic Chinese hamsters and their non-diabetic siblings. Diabetologia 3, 92-96 (1967).

45. Wright, D.L., Carpenter, A-M.: B-cell volumes in normal and sub-diabetic rats. Anat. Rec. 139, $287-$ 288 (1961).

46. Beloff-Chain, A., Rookledge, K.A.: The metabolism of glucose in diaphragm muscle from normal rats, from streptozotocin-treated diabetic rats and from rats treated with anti-insulin serum. Biochem. J. 110, $529-532(1968)$.

47. Duff, G.L., McMillan, G.C., Wilson, D.C.: Hydropic changes in panereatic ductules and islets in alloxan diabetes in the rabbit. Proc. Soc. exp. Biol. Med, 64, $251-255(1947)$. 
48. Goldner, M.G.: Alloxan diabetes, its production and mechanism. Bull. N.Y. Acad. Med. 21, 44-55 (1945). 49. Kennedy, W.B., Lukens, F.D.W.: Observations on alloxan diabetes. Proc. Soc. exp. Biol. Med. 57, 143149 (1944).

50. Kvistberg, D.R., Lester, G., Lazarow, A. : Staining of insulin with aldehyde fuchsin. J. Histochem. Cytochem. 14, 609-611 (1966).

51. Schein, P.S., Loftus, S.: Streptozotocin: depression of mouse liver pyridine nucleotides, Cancer Res. 28, $1501-1506$ (1968).

V. Hoftiezer, Ph.D.

Northwest Center for Medical Education

Indiana University

3400 Broadway

Gary, Indiana 46408

USA 